\title{
SHOPPING BEHAVIOR OF INTERNET USERS IN SERBIA
}

\author{
Đurić Slađana $^{1}$
}

\begin{abstract}
The Internet and its media and platforms are inevitable and very powerful assets of contemporary business. Marketers use the Internet and its potential for launching online advertising campaigns and for establishing and maintaining successful long-term relationship with customers. The customer relationship approach based on the usage of digital technologies and the Internet has transferred the communication between companies and their customers online and became a crucial tool for achieving the competitive advantage in the today's turbulent market space. The research results presented in this paperwork represent a significant part of a wider research undertaken by the author with the aim to explore the actual attitudes of Serbian citizens to their usage of the Internet, social media and their online shopping behavior.
\end{abstract}

Key words: the Internet, social media, social network, multiple channels of distribution, online purchasing, research

\section{INTRODUCTION}

Intensive development of digital technologies, shorter lifecycle of products, the Internet, social media, smartphones and educated, connected and informed customers have transferred not only our communications, but the whole business online. The usage of the Internet and social networks have enabled people to interact globally with minimal effort, but made the battle for attaining and sustaining the

\footnotetext{
1 Univerzitet Novi Sad, Ekonomski Fakultet u Subotici, e-mail: sladjana.djuric@sgsmitrovica.rs
} 
competitive advantage very difficult and uncompromising. Not only have our communications become passive, but the way we shop has drastically changed due to the usage of digital technologies. The Internet has enabled potential buyers to search for the desired products/services from their living room, to read other users' reviews, compare prices, purchase products online and keep track of their orders. "The website can be seen as a mix between direct selling (as it engages the visitor in a dialogue) and advertising because it can generate awareness, provide information, and demonstrate the product" (Yannopoulos, 2011). A website taking longer than 2-5 seconds to upload, slow order processing, a longer period of delivery, the shortage of desired products, inadequate products delivered and long complaint procedures are all serious failures that can jeopardize the existence of one company. The Internet and its related technologies have transformed traditional shopping into "ecommerce, s-commerce, f-commerce, e-tailing" and caused the customers to be more informed, better connected, more involved and much more demanding than ever before.

This research was undertaken as an attempt of the author to show that online advertising has become too aggressive and that online space is overloaded by advertising content. People mostly use the Internet to search for information of interest for them (such as news, health information, job vacancies, information about products and services they intend to buy), to participate in social networks, send/receive e-mails, watch movies, read e-books etc. Their activities on the Internet are interrupted by advertisements coming in various forms, and it is the opinion of the author that this causes negative attitude towards online advertising. The intention of the author was to investigate real attitudes of people towards the Internet and their actual attitudes and habits related to online shopping.

\section{LITERATURE REVIEW}

"Customers all over the globe are demanding more channel options for gaining access to products and services while technology has made it possible and economically feasible for firms to offer wider array of channels, especially Internet-based online channels" (Rosenbloom, 2007) and therefore applying the multichannel distribution strategy is necessary for companies to sustain the competitive advantage in turbulent global market. 
The social media and social networks have made people's communication public and transparent, and companies must take into consideration the constant monitoring of their audience's online behavior and habits in order to provide adequate and efficient response to their demands and needs. Data gathered from such researches may present valuable guidance in further customer relationship activities.

The research presented in this paperwork is the result of the research undertaken in 2018 with the intention to gather information about the experience and attitudes of Serbian Internet users related to their usage of the Internet, social media and online shopping.

In April 2017, the Serbian Bureau of Statistics (Republički Zavod za Statistiku) published a report presenting the rates of usage of Internet and e-commerce among Serbian users. This report was studied and used by the author of this paper as an idea for the research presented here. Another source, taken as the guidance when conducting this study, was the Master thesis from Wang and Abdullayeva (2011) which contained the analysis of e-commerce, social media and social commerce and its application in customer relationship improvement. Ghaith, Khaldoon and Anas (2014) analyzed the Internet as the channel of distribution and its effects on the reduction of the number of intermediaries in distribution channels in Jordanian companies in general. These studies deal with different aspects of Internet usage and, as such, have provided business models and methods taken as the grounds for this survey.

Osterwalder (2002) stated that the Internet has the potential to complement rather than to cannibalize a business's channels and until today the usage of the Internet for business (data bases, data mining, email, social networks, web presentation, online conference, real-time transmissions etc.) became the core of almost every business activity. The Serbian Bureau of Statistics (Republički Zavod za Statistiku, 2018) published the figures of their annual research related to the usage of digital technologies in Serbia, and reported that 3,590 million Serbian citizens use the Internet daily (290 000 more that in 2017), 4,910 million people use mobile phones and 77.6\% respondents acces the Inernet via mobile phone. According to the same report, 1,800 million people purchased or ordered products/services online in the period of one year (130 000 more than in 2017). The same report highlighted that $80.1 \%$ of employed respondents used the Internet to communicate via e-mail, $22.5 \%$ use the social networks for business, $86 \%$ of companies (out of 
1781) have a web-site adjusted to their regular visitors, $86 \%$ have their products/services description available on the web-site and $25.1 \%$ offer the posibilty to order or make reservations online.

Rosenbloom (2007) argued that "product differences whether based on technological superiority, design innovation, quality or brand identity, can be copied, matched or even improved upon competitors from all over the world in a relatively short period of time" and therefore the implementation of multichannel strategies is the imperative for companies in global market. High quality products and services are no longer sufficient if we want to attract customers and secure high selling rates. Companies are obliged to predict their customer's needs and desires and satisfy those needs in the time and place they find suitable and acceptable. Products/services must be competitive in terms of price, quality, delivery and must satisfy customers completely. Failing to comply with customer's standards might lead to a negative propaganda (word-of-mouth advertising) and cause customers to leave the company and its brand for some other competitor on the market.

The online presence and online communication, as part of a communication strategy, need to be systematically planned and carried out to maintain constant contact with the brand fans, and yet that communication must not be too aggressive and excessive. Saturation of online space with advertisements, interruptions of videos and audio contents, spam e-mails and ads coming out from every corner of the screen while surfing web-sites (banners) provoked many Internet users to install ad-block applications. According to Deloitte (2017), the desktop and laptop ad blocking rate increased up to 30\%, and users of adblocking software can be characterized as younger, employed, with higher education and a higher income. Mobile ad-blocking has lower rates, and mobile phones and smartphones are still the most attractive means to get around ad blocking and to reach younger audience. Still, ads that are not easy to block are also increasing and it appears that the battle between marketers and people who want to be left to surf the Internet and to use their mobile phones free of advertisements continues.

According to Kotler and Keller (2006) the effective web-site should contain the following attributes: 
- Context- layout and design

- Content- text, pictures and sounds incorporated in the web design

- Community - the way that the web-site enables communication between its users

- Customization and adjustment- the ability of the web-site to accommodate to different users or to enable users to personalize the web-site

- Communication - how the web-site enables two-way communication (from the web-site to the user and from the user towards the website)

- Connection - linking with other web-sites

- Commerce - to enable commercial transactions

- Constant change - constant customization and adjustment

To attract and to bind customers, companies must provide them with updated and useful content: news, texts, videos, free e-books, reports, studies, research results, manuals, how-to guides, reviews, answers to their questions etc. It is the imperative that web-site layout enables its visitors to move through the content easily, that fonts are easy to spot and read, that audio and video contents upload quickly and are easy to share. An attractive web-site needs to have good linking with other similar web contents to ensure that its visitors are able to find useful information in a very short period of time and with minimal jamming.

To ensure effective online presence, companies and entrepreneurs must invest in technologies and qualified personnel. Trained and skilled sales personnel is important as much as competent administrators of online communication channels to maintain and improve long-term relationships with customers. Loyalty is very fragile in the today's constantly changing market conditions and therefore all sectors and resources of the company must be oriented and recruited to create the validity, value, venue and vogue. (Đurić, 2018) It is not enough to create and deliver the product/service in due time and to a desired premise, but it is of crucial importance to anticipate the needs and desires of customers and to act in accordance with the emerged trends of environment protection and social awareness. The growth of living standards, health awareness, more time available for hobbies and interests and the need for possessing brands, as the affirmation of one's lifestyle, have promoted the necessity to satisfy public opinion and achievement of higher goals. 
To surpass the planned market share and to sustain the competitive advantage it is necessary for companies and entrepreneurs to create a business approach that includes multichannel distribution strategy and online media usage to reach targeted customers and to create strong relationships with them. Taking that into consideration, companies must create a business model that implies the following basics:

- Accessing the market with the products and services of supreme quality in order to stimulate potential buyers to purchase those products/services.

- Carrying out comprehensive market research including studying online behavior and purchasing habits and patterns of their potential customers.

- Entering online space with functional web-sites and social media pages in order to communicate with targeted segments of customers

- Undertaking powerful actions related to establishing and fortifying relationship with their customers by implementing the necessary actions to maintain individualized and close contact through communication channels that customers prefer, in time and occasion they choose

- Providing assets, resources, technology and skilled personnel to maintain the constant follow-up on the preferences, needs and desires of chosen segments of customers.

Prashar, Vijay and Parsad (2017) studied the behavior of Indian online shoppers and conducted comprehensive research related to different variables of offline and online environment on consumer's online behavior. They measured online shopping values (hedonic and utilitarian) and purchase intention. They also measured the opinion of Indian online shoppers about websites informativeness, website entertainment and effectiveness, and information content satisfaction. Prashar, Vijay and Parsad (2017) came to conclusion that the online shopping has become a mode of entertainment and driving pleasure, and that online retailers must customize marketing and promotional strategies to specific markets by providing exciting, entertaining and enjoyable e-shopping environment, besides their product offering.

Statista web-site (Statista, 2019) ranked the most popular social networks and platforms, according to the number of active users per month, as follows: Facebook (2,320 billion), YouTube (1,900 billion), 
WhatsApp (1,600 billion), Facebook Messenger (1,300 billion), Instagram (1,000 billion), Twitter (330 million), Linkedin (303 million) etc. These numbers emphasize the huge potential of social media and mobile phone applications for online campaigns, but the ratio that will satisfy both marketers and the audience they intend to target, needs to be achieved. The income loss caused by ad avoidance (not watching ads on TV, changing channels during commercials, fast-forwarding TV ads, skipping ads while watching videos, leaving web-sites with ad block control, clicking the " $\mathrm{x}$ " in the corner of appearing banners etc.) is becoming significant and trying to find a compromise in this situation will be the challenge for marketers.

\section{METHODOLOGY}

This research was undertaken as a part of research study of the Internet and online campaigns. The main goal of this research was to gain the knowledge about the attitudes and experiences of adult Serbian citizens related to their usage of the Internet, social networks and e-commerce with the intention to show the potential of the Internet and social media for planning and creating online campaigns. Behavioral patterns and habits of Internet and social media users are valuable data for marketers when planning their online presence. Information that social media users post daily may be used by marketers to personalize their customer relationship approach and to reach individual customers, respecting their online schedule and preferences.

The questionnaire containing 30 questions was created in three sections. The first part was related to demographic characteristics: sex, age, education, employment data and monthly income. The second section covered questions related to Internet usage: what device they use to access the Internet, which applications they use, the purpose of Internet usage, the type of social network/platform they participate in etc. The third set of questions was about online shopping. This paperwork presents attitudes and opinions of research participants about purchasing products/services online and their attitudes towards online advertising, data protection, ad blocking and customer's rights awareness.

The questionnaire was distributed (50\% in paper, $30 \%$ via e-mail and $20 \%$ via Facebook) to 252 participants older than 18 years of age. 
Younger participants were not included in order to comply with the main goal of the research- to study people with already established buying patterns and attitudes and with a monthly amount disposable for online shopping. Participation in the survey was anonymous and voluntary and questions were designed to make it easier for participants to provide honest and clear answers Some questions were in a direct open form (yes/no) and some (including demographic criteria) were designed to mark the specific criteria that applies for each individual respondent. The response rate was $100 \%$ and no questionnaire was returned blank. The participants in the survey were chosen randomly among workers of the following companies: JP "Vojvodinašume" in Petrovaradin, JP "Vodovod" in Sremska Mitrovica, Public Attorney's Office in Sremska Mitrovica, The Serbian Business Registers Agency in Belgrade, Karate Club "Sirmium" in Sremska Mitrovica, Hairdressing salon "Milena" in Šid, Gallery "Sava Šumanović" in Šid, on the territory of Šid, Sremska Mitrovica, Novi Sad, Belgrade and Užice. Some visitors of coffee bars and restaurants and clothes stores in mentioned towns were also randomly questioned.

Prior to statistical data processing, the author set the following hypothesis related to online shopping patterns and experiences of respondents:

H1: Consulting the Internet prior to making a decision to purchase some product/service is significantly affected by the education of participants.

H2: Age and education level of participants affect the usage of ad blocking applications.

H3: Monthly income is related to the willingness of participants to react to Internet advertisements.

H4: Monthly income affects purchasing of products/services on the Internet.

H5: Age of participants determines the trust of participants related to online ads and people in their surroundings.

Results gathered in the field are processed by statistical analysis (MANOVA, ANOVA) and described and explained in order to display the correlation between the demographic characteristics of respondents and their online behavioral patterns (usage of the Internet, social media and online shopping). This paper will mainly present results related to online shopping. 


\section{RESEARCH RESULTS}

This table presents general socio-demographic characteristics of research participants.

Table 1: General socio-demographic characteristics of research participants (total number of participants: 252)

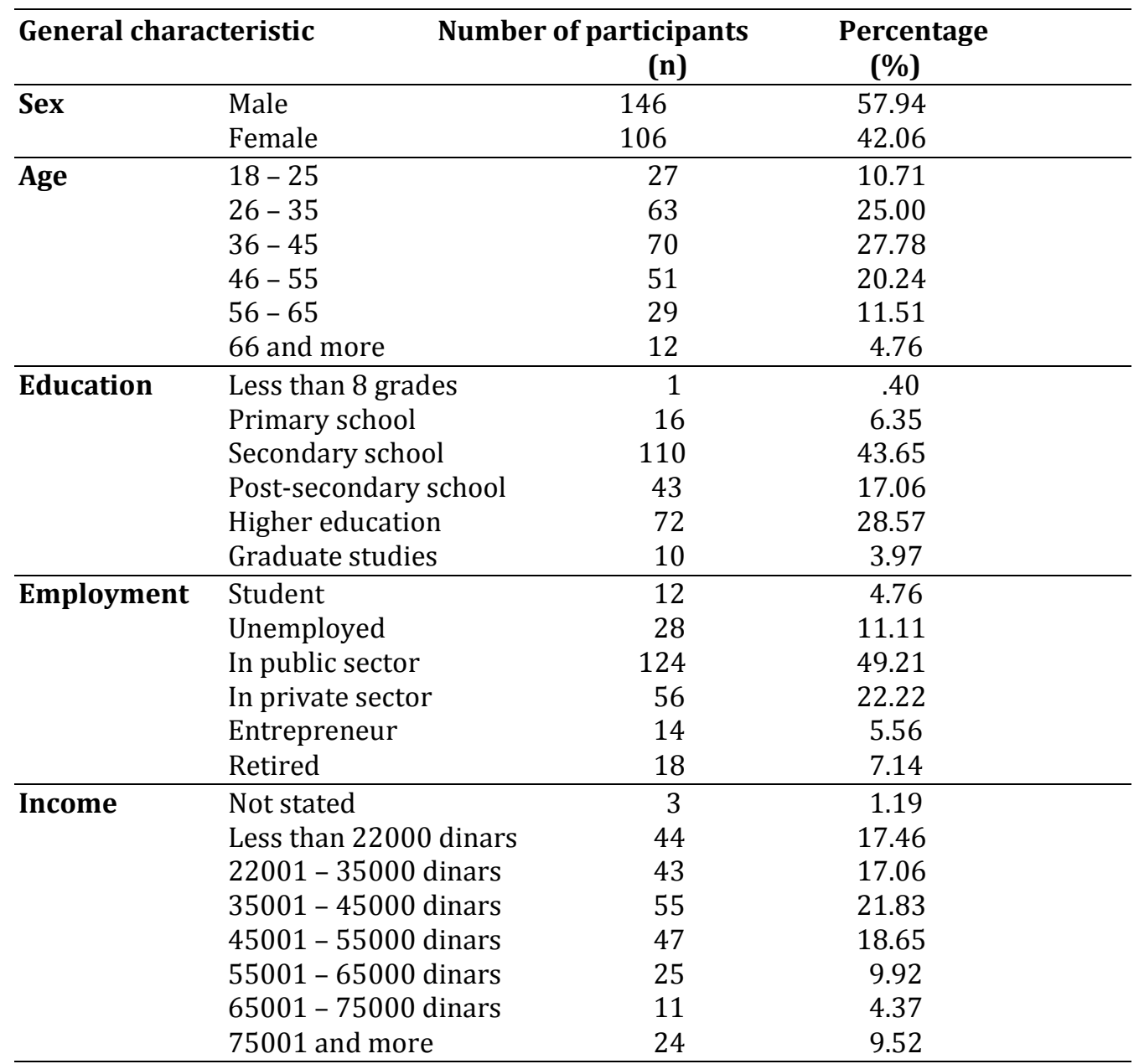

Source: Author's data

Out of 252 participants, 239 (94.84\%) claimed that they use the Internet. $\mathrm{H} 1$ : Consulting the Internet prior to making decision to purchase some product/service is significantly affected by the education of participants. 
Table 2: Consulting the Internet prior to making decision to purchase the product/service (exploring characteristics of the product/service, availability, discounts, prices comparison etc.) related to the educational criteria

\begin{tabular}{lllll}
\hline ANOVA & $\chi$ & R & F & p \\
\hline $\begin{array}{l}\text { Do you consult the Internet prior to making } \\
\text { decision to purchase the product/service }\end{array}$ & 2.5 & 0.4994 & 2.448 & 0.034 \\
\hline
\end{tabular}

Source: Author's data

$\mathrm{P}$ value $\mathrm{p}<0.05$ proves that the education is related to the habit of participants to consult the Internet before they make the decision to purchase some product/service, and therefore the H1 is valid. Post-hoc ANOVA analysis indicated, with deduction level $p<0.1$ the difference between participants who graduated from university and those with primary school $(\mathrm{p}=0.09)$, since most participants who have completed primary school answered negative to this question (56,3\%) and participants who graduated from university mainly answered positive (86.1\%). Further alalysis indicated that 77 (out of 110) participants who have completed secondary school, 36 (out of 43) participants who have completed a postsecondary school, 62 (out of 72) participants who graduated from university and 9 out of 10 who completed graduate studies answered that they consult the Internet prior to making decision whether to buy some product/service on the Internet. When testing age and the habit to consult the Internet prior to making purchasing decision positive answers were given as follows: age $18-25: 77.8 \%$ participants, age 26-35: 79.4\% participants, age 36-45: 78.6\% participants, age 46-55: 78.4\% participants and age 56-65: 86.2\% participants answered positive to consulting the Internet prior to making purchasing decision.

H2: The age and education of participants affect the usage of ad blocking applications.

Table 3: The usage of ad blocking applications related to the age of participants

\begin{tabular}{lllll}
\hline ANOVA & $\chi$ & $\mathbf{R}$ & $\mathbf{F}$ & $\mathbf{p}$ \\
\hline Do you use some ad blocking application & 4.06 & 0.813 & 2.7 & 0.021 \\
\hline ANOVA & $\chi$ & $\mathbf{R}$ & $\mathbf{F}$ & $\mathbf{p}$ \\
\hline Do you use some ad blocking application & 4.06 & 0.813 & 2.7 & 0.021 \\
\hline
\end{tabular}

Source: Author's data 
Value of $\mathrm{p}<0.05$ indicates that the age of participants affects the usage of ad blocking applications. Post-hoc ANOVA revealed the difference between participants of age $66+$ and those of age 36- 45 since $p=0.025$ and participants of age 66+ and those of age 46-55 (for $\mathrm{p}=0.02$ ). Participants of age $66+$ answered negative to ad blocking in percentage of $58.3 \%$, participants of age 36-45 answered positive in percentage of $30 \%$ and participants of age 46-55 answered positive in percentage of $27,5 \%$. When tested, with the significance level of $p<$ 0.1 the difference was found in answers of groups of $66+$ and $26-35$ (p $=0.07)$ and among groups $66+$ and participants of age 56-65 $(\mathrm{p}=$ 0.064). Participants of age 26-35 answered positive to ad blocking in percentage of 33,3\%, participants of age 36-45 answered positive in percentage of $30 \%$ and participants of age 56-65 answered positive in percentage of $24,1 \%$.

Table 4: The usage of ad blocking applications related to educational criteria

\begin{tabular}{lllll}
\hline ANOVA & $\chi$ & $\mathbf{R}$ & $\mathbf{F}$ & $\mathbf{p}$ \\
\hline $\begin{array}{l}\text { Do you use some ad blocking } \\
\text { application }\end{array}$ & 4.95 & 0.989 & 3.325 & 0.006 \\
\hline
\end{tabular}

Source: Author's data

The table above indicates that the education affects the usage of ad blocking applications, since $\mathrm{p}<0.05$, and therefore $\mathrm{H} 2$ is valid. When testing education and ad blocking, it was determined that $12.5 \%$ of participants who completed primary school answered positive to ad blocking usage $(\mathrm{p}=.014)$, participants who completed secondary school answered positive in percentage of $17.3 \%(\mathrm{p}=.000), 34.9 \%$ of participants who have completed high schol $(\mathrm{p}=.006)$ use ad blocking as well as the participants who have completed faculty $(40.3 \%, \mathrm{p}=.032)$ and postgraduates $(60 \%, \mathrm{p}=.008)$.

H3: The monthly income is related to the willingness of participants to react to Internet advertisements.

H4: The monthly income affects the purchase of products/services on the Internet. 
Table 5: The relation between the monthly income and the willingnes of participants to react to Internet advertisements and online purchasingMANOVA analysis

\begin{tabular}{llll}
\hline Analysis & $\mathbf{n}$ & $\mathbf{F}$ & $\mathbf{P}$ \\
\hline MANOVA & 6 & 1.578 & .007 \\
\hline
\end{tabular}

Source: Author's data

$P$ value set at $p=.007$ shows that the monthly income is related to the willingness of participants to react (to click and to watch) to Internet advertisements (ads appearing while watching some content on the Internet, like videos and music, banners, ads received on mobile phone and Viber, ads received via e-mail and ads on social networks). The monthly income also affects the purchase of products/services on the Internet.

Table 6: The relation between the monthly income and the willingnes of participants to react on the Internet advertisemenst and online purchasingANOVA analysis

\begin{tabular}{|c|c|c|c|c|}
\hline ANOVA & $\chi$ & $\mathbf{R}$ & $\mathbf{F}$ & $\mathbf{P}$ \\
\hline $\begin{array}{l}\text { Do you follow (click and watch) } \\
\text { ads appearing while you watch videos } \\
\text { and music }\end{array}$ & .354 & .327 & 4.192 & .000 \\
\hline Do you follow (click and watch) banners & .324 & .304 & 3.567 & .000 \\
\hline $\begin{array}{l}\text { Do you follow (click and watch) ads } \\
\text { received on } \\
\text { mobile phone and Viber }\end{array}$ & .266 & .269 & 2.736 & .010 \\
\hline $\begin{array}{l}\text { Do you follow (click and watch) ads } \\
\text { received via } \\
\text { e-mail }\end{array}$ & .285 & .283 & 3.038 & .005 \\
\hline $\begin{array}{l}\text { Do you follow (click and watch) ads on } \\
\text { social networks }\end{array}$ & .305 & .273 & 2.824 & .008 \\
\hline $\begin{array}{l}\text { Do you purchase products/services on } \\
\text { the Internet }\end{array}$ & .242 & .222 & 1.822 & .083 \\
\hline
\end{tabular}

Source: Author's data

ANOVA analysis implies that $\mathrm{H} 3$ and $\mathrm{H} 4$ can be accepted for the sample of 252 Serbian citizens, since the relation between the monthly income and the willingness of participants to react to Internet advertisements and their online purchasing is evident for all values $\mathrm{p}<1$. Post-hoc ANOVA revealed differences between participants with monthly income 4500155000 dinars and 22001- $35000(\mathrm{p}=.008)$ and participants with income 
45001-55000 and less than $22001(\mathrm{p}=.002)$. This group of participants replied mostly negative to watching ads appearing while watching videos and music. The same group of citizens had more negative answers to watching banners than groups of participants with income less than $22001(\mathrm{p}=.069), 22001-35000(\mathrm{p}=.036)$ and participants with income 65001-75000 ( $\mathrm{p}=.072)$. Participants with income 55001-65000 had more negative answers than groups with a monthly income below 22001 $(\mathrm{p}=.035)$ and 22001-35000 ( $\mathrm{p}=.043)$ related to watching ads on Viber or mobile phones. Participants with a monthly income 75001 and more had more negative answers to watching e-mail ads than those with an income below $22000(\mathrm{p}=.049)$. Participants with a monthly income of 4500155000 and 55001-65000 had more negative answers to watching ads on social networks than participants with an income below $22000(\mathrm{p}=.055$ and $\mathrm{p}=.065$ ). Participants with a monthly income of 75001 dinars and higher replied positively to buying goods on the Internet, compared to participants with an income of 65001-75000 ( $\mathrm{p}=.018)$ and 22001-35000 (p=.027).

Further analysis (of the sample of 252 Serbian citizens) showed that participants with a monthly income of 45001-55000 dinars and 5500165000 dinars answered negative to following ads appearing while watching videos and music in percentage of $84 \%$ and $87.2 \%$ respectively. In fact, participants with monthly incomes of 22001-35000 dinars, 35001-45000 dinars, 65001-75000 dinars and 75000 dinars and higher had a very high percentage of negative answers related to this question (62.8\%-80\%). Participants with a monthly income of 45001-55000 dinars and 55001-65000 dinars had a negative answering rate (over $80 \%$ ) to reacting to banners. Other participants with monthly incomes of 22001-35000 dinars, 35001-45000 dinars, 65001-75000, over 75001 dinars answered negative to following banners in parcentage 54.5\%$79.2 \%$. Respondents with a mothly income of 35001-45000 dinars, 45001-55000 dinars, 55001-65000 dinars, 65001-75000 dinars and 75001 and more replied negative to watching ads received via e-mail in percentage $54.5 \%-75 \%$. Related to ads on social networks, respondents of the same groups of monthly incomes responded negative in percentage $54.5 \%-74.5 \%$. The highest rates of positive answeres, when asked whether they buy products/services on the Internet, had participants with incomes 55001-65000 dinars (76\%) and 75001 and more $(79.2 \%)$. 
H5: The age of participants define the trust of participants related to online ads and people in their surroundings.

When put in correlation and analysed, the age of respondents affected the answers when they were asked if they trusted online advertisements more than the opinion and experiences of people in their surroundings related to the product/service they intent to buy.

Table 7: The age of participants related to the trust of participants in online ads and people in their surroundings

\begin{tabular}{lllll}
\hline ANOVA & $\chi$ & $\mathbf{R}$ & $\mathbf{F}$ & $\mathbf{p}$ \\
\hline $\begin{array}{l}\text { Do you trust the online } \\
\text { advertisements more than the } \\
\text { opinion and experience of people } \\
\text { you are surrounded with }\end{array}$ & 3.26 & 0.653 & 3.675 & 0.003 \\
\hline
\end{tabular}

Source: Author's data

Value $\mathrm{p}<0.05$ demonstrate that the age of respondents affected the answers of participants when asked if they trusted online advertisements more than the opinion and experiences of people in their surroundings related to the product/service they intent to buy. Post-hoc ANOVA revealed the differnce between groups of participants of age 2635 and 18-25 (p=0.03), participants of age $66+$ and $26-35(\mathrm{p}=0.02)$ and groups of participants of age $66+$ and $46-55(\mathrm{p}=0.03)$. Partcipants of age 18-25 mainly answered negative to this question (74.1\%), as well as partcipants of age 26-35 (93.7\%), participants of age 36-45 (87.1\%), 46$55(90.2 \%), 56-65(86.2 \%)$ and $66+(75 \%)$. According to the age criteria the results were as follows: 59 (out of 63) participants of age 26-35, 61 (out of 70) participants of age 36-45 and 46 (out of 51) participants of age 46-55 replied negative to this question. When asked if they believed online ads more than they believe the opinion of people from their surroundings, $75 \%$ of participants who have completed primary school, $89.1 \%$ of participants who have completed secondary school, $81.4 \%$ of participants who completed postsecondary education, $88.9 \%$ with a university degree and $100 \%$ of those who completed less than 8 grades of primary school and postgraduates, replied negative, so H5 may be considered valid.

ANOVA analysis of the sample of 252 participants did not indicate any significant results when testing the effects of monthly income and following questions: 
Table 8: The monthly income related to some online purchasing behaviour ANOVA p value

Do you trust online advertisements more than the opinion and experience of people you are surrounded with

$\mathrm{p}>0.05$ experience of people you are surrounded with

Do you read other users' reviews when making a decision to purchase some product/service

Did you give up on buying some product/service beacuse of negative comments on the Internet or people from your surroundings

Are you annoyed by the advertisements you receive via e-mail or mobile phone

$p>0.05$

$\mathrm{p}>0.05$

$\mathrm{p}>0.05$

Do you follow ads on the Internet

$p>0.05$

Do you consult the Internet prior to making a decision to

$\mathrm{p}>0.05$ purchase a product/service

Did you buy any product online in last three months, six $\mathrm{p}>0.05$ months, 12 months

Source: Author's data

When asked about their experience with online shopping, 63.49\% (160 participants) stated that they were satisfied and $60.71 \%$ of them did not have any complaints. 
Table 9: Cronbach Alpha coefficient

\begin{tabular}{|c|c|c|}
\hline Domain & Number of items & Cronbach Alpha value \\
\hline Online buying habits & 35 & 0.848 \\
\hline All questionnaire & 72 & 0.854 \\
\hline
\end{tabular}

Source: Author's data

The reliability values for the research constructs in the whole questionnaire are within values $0.83-0.88$.

Table 10: Other relevant statistics

\begin{tabular}{|c|c|c|c|}
\hline $\begin{array}{l}\text { Question } \\
\text { (in \%) No answer }\end{array}$ & & Yes (in \%) & No \\
\hline You use the mobile phone to access the Internet & 77.78 & 22.22 & \\
\hline $\begin{array}{l}\text { You consult the Internet prior to purchasing product/ } \\
\text { service (exploring characteristics of products/ } \\
\text { services, availability of products/services, } \\
\text { discounts, comparison of prices etc.) }\end{array}$ & 75.00 & 22.62 & 2.38 \\
\hline $\begin{array}{l}\text { Are you a member of some brand fans community } \\
\text { (brand fan page on Facebook, Instagram etc.) }\end{array}$ & 15.87 & 81.75 & 2.38 \\
\hline Do you use ad block program/application & 28.17 & 67.86 & 3.97 \\
\hline $\begin{array}{l}\text { Are you annoyed by ads you receive via e-mail } \\
\text { or mobile phone }\end{array}$ & 47.62 & 49.60 & 2.78 \\
\hline $\begin{array}{l}\text { Are you worried that information you provide when } \\
\text { you fill out online ordering form might be } \\
\text { misused }\end{array}$ & 55.16 & 42.06 & 2.78 \\
\hline Do you participate in online winning contests & 15.88 & 80.95 & 3.17 \\
\hline Do you trust online advertising campaigns & 18.65 & 78.57 & 2.78 \\
\hline $\begin{array}{l}\text { Do you read reviews form other users (posts, } \\
\text { comments, forums) about products/ } \\
\text { services you are planning to buy }\end{array}$ & 66.67 & 30.16 & 3.17 \\
\hline $\begin{array}{l}\text { Do you buy products/services on the Internet } \\
\text { Did you give up on buying some product/service } \\
\text { because of negative comments of other }\end{array}$ & 60.72 & 37.30 & 1.98 \\
\hline $\begin{array}{l}\text { Internet users } \\
\text { or people from your surrounding }\end{array}$ & 61.50 & 30.56 & 7.94 \\
\hline Are you aware of customer's rights & 68.25 & 27.78 & 3.97 \\
\hline
\end{tabular}

Source: Author's data

The figures above reveal that the usage of mobile phones for accessing the Internet and ad blocking usage in Serbian sample of 252 citizens fit in global statistics figures. It is also evident that participants mainly don't trust online advertising, don't participate in online award contests and 
feel worried about the safety of their online data. Most participants read reviews from other users related to products/services they want to purchase $160 \%$ of those who completed secondary school, $76.7 \%$ of those who completed postsecondary schools, $80 \%$ of participants who have completed higher education and $81.9 \%$ of postgraduates) and consult the Internet before they make purchasing decision.

While testing the hypothesis related to the usage of the Internet and social media, the statistical analysis revealed that the age of participants significantly defines the purpose of Internet usage. It was shown that respondents of age 36-45 and 46-55 use the Internet when seeking information of interest for them (news, health, entertainment etc.). Respondents of age 18-25 and 26-35 use the Internet to take part in social networks (younger population). Respondents of 36-45 and 46-55 mainly use the Internet to find information about products/services (characteristics of products/services, prices, availability etc.) and to send/receive e-mail and respondents of age 26-35 and 36-45 purchase products/services online. According to the education criteria, it was determined that respondents who have completed secondary school, postsecondary school and university access the Internet to find the information of interest for them. Those with secondary education and higher education use the Internet when searching for information about product/services and those who have graduated from university and postgraduates use the Internet when communicating via e-mail. Participants with higher education buy products/services online and those with a university degree and master's or doctoral degree reserve/buy holiday arrangements and airplane tickets online. Participants of all educational categories had a high response rate to the usage of Internet to participate in social networks and low to the usage of Internet for e-banking.

Participants of age 18-25 and 26-35 mainly participate in social networks Facebook, YouTube and Instagram and participants of age 3645 read blogs online. Over $80 \%$ of respondents of age categories 26-35 and 36-45 consult the Internet prior to making decision on purchasing products/services and participants of age 18-25 and 36-35 follow online advertisements. Respondents of age 46-55 mainly don't follow ads on the Internet (70.6\%). Analysis revealed that $71.2 \%$ of women participate in social network Facebook and that $79.2 \%$ of men watch videos on YouTube. When asked if they participate in social networks such as 
Twitter, Pinterest and Linkedin, both men and women replied mainly negative (over $88 \%$ ). Related to online shopping, $63.7 \%$ of women and $56,6 \%$ of men responded positively. When asked if they gave up on purchasing some product/service because of negative comments of other Internet users or negative comments of people they are surrounded with, participants who have completed high school (67.4\%), faculty $(66.7 \%)$ and postgraduates (90\%) answered positive. Participants who completed secondary school (62.7\%), high school (67.4\%), faculty $(77.8 \%)$ and $90 \%$ of postgraduates are aware of the customer's rights.

\section{DISCUSSION}

The main reason for this research was to test real attitudes of Serbian citizens related to online shopping and their feelings about Internet advertising.

When testing education and age criteria and the habit to consult the Internet before purchasing some product or service (to search for information about products, availability, discounts etc.) the highest positive answering rates were gained in groups of highly educated people (secondary school, high school, faculty and postgraduates) and among people of almost all ages 18-25, 26-35, 36-45, 46-55 and 56-65. The Internet is by all means a very important source of information for people and might affect the decision of participants to buy some product or service.

Related to ad blocking, the results of this test were expected. Older population in our sample answered negative to ad blocking usage in percentage of $58.3 \%$, but other groups of participants fit in global statistics of approximately 30\%. According to educational criteria, participants who are highly educated are more open to ad blocking usage. The increase of ad blocking globally (our sample fits in global statistics) indicates that the Internet space is overcrowded with advertising and people try to avoid it by blocking it. This leads to a serious loss of revenue from Internet advertising, since huge amount of these ads will never be seen by potential buyers.

The purpose of comparing monthly income of participants in this sample and their willingness to watch different advertising content (that appears while they surf the Internet searching for information of interest for 
them) was to show that participants with highest monthly incomes disposable for online shopping are reluctant to pay attention to Internet advertising.

Most participants in this Serbian sample replied negative when asked if they believed Internet advertising more than people in their surroundings, which indicates that word-of-mouth advertising has stronger influence on potential buyers in this sample than Internet advertising content. Also, participants answered positive in percentage of $66.67 \%$ to reading reviews of other Internet users, which supports above mentioned advantage of word-of-mouth advertising over Internet advertising. Even though $60.72 \%$ of participants stated positive to buying products/services online, $61.50 \%$ of them did not buy product/service they initially intended to buy due to negative comments of other Internet users.

Other statistics revealed that many participants are annoyed by advertising content that interrupts their activities while surfing the Internet and feel worried that their personal data revealed while ordering goods online might be misused. Participants responded mainly negative to participation in online winning contests and to membership in online brand fun pages communities.

The percentage of those participants who are aware of basic customer's rights (68.25\%) indicates that Internet shoppers in our sample are well informed and educated.

Results of this research in general indicate that the Internet space is saturated with advertising content and that online marketing strategies and customer relationship strategies need to be adjusted to actual attitudes and opinions of Internet users.

\section{CONCLUSION}

The figures on global usage of the Internet and social media raise the awareness of its huge potential for planning and launching very successful online activity for companies and entrepreneurs. The Internet and its applications and platforms offer marketers various tools for reaching individual customers and creating strong and powerful relationships with them. Communications are transferred to the online world and direct face-to-face contacts have reduced in favor of passive 
online communication. The Internet and mobile users spend a significant amount of time communicating online and that is a perfect opportunity for marketers to promote their products and services online, but the aggressive and excessive online advertising have provoked ad blocking usage to increase. A huge amount of information and data posted daily on social media by its users represent a considerable database of online behavioral patterns and should be used as guidance for reaching them in time and manner they accept.

This research was undertaken in order to gain the insight into actual attitudes and experiences of Serbian citizens regarding the Internet, social media and online purchasing. The questionnaire was created after exploring the work and methodology of some other researchers in this area of expertise and may be replicated, adjusted and used in other similar researches. Even though the research included only 252 participants, the results gained after observation and statistical analysis pretty much correspond to global statistics. The results of this research point out that people with established habits and attitudes (population of age 26-65), highly educated people and those people with a higher monthly income disposable for shopping online, mainly don't trust online advertisements, don't follow online ads and are more influenced by the opinion of people from their surrounding and other Internet users than online advertising messages. Studies like this one offer companies a realistic insight into the attitudes of potential buyers regarding their willingness to accept their online approach and might point out the strengths and weaknesses of online customer relationship strategies.

\section{REFERENCES}

1. Deloitte (2017). Is there an \#Adlergic epidemic? Ad blocking across media, The Creative Studio at Deloitte, London, access June 2019 https://www2.deloitte.com/content/dam/Deloitte/global/Images/infogra phics/technologymediatelecommunications/gx-deloitte-tmt-2018adblocking-media-report.pdf

2. Đurić, S. (2018). Research paperwork: Marketing on the Internet and the online campaign, Course: Contemporary marketing trends, Faculty of Economics in Subotica.

3. Ghaith M. A., Khaldoon H. K., Anas Y., H. (2014). Internet Usage and Traditional Distribution Channels: The Moderating Effect of the Firm's Size in Jordan, International Business Research, 7(3), 81-90. 
4. Kotler, P., Keller, K.L. (2006). Marketing management, $12^{\text {th }}$ Edition, Data Status, Belgrade.

5. Osterwalder A. (2002). An e/Business Model Ontology for Modeling eBusiness, $1^{\text {th }}$ Bled Electronic Commerce Conference; eReality:Constructing the e-Economy, Bled, Slovenia, June 17-19, 2002.

6. Prashar S., Vijay T.Sai, Parsad C, (2017). Effects of Online Shopping Values and Website cues on Purchase Behaviour: A Study Using S-O-R Framework, Vikalpa - The Journal for Decision Makers, 42(1), 1-18.

7. Republički Zavod za Statistiku (2017). Upotreba Informacionokomunikacionih Tehnologija u Republici Srbiji; Domaćinstva/Pojedinci, Preduzeća, Republički Zavod za Statistiku, Beograd, access April 2018 http://publikacije.stat.gov.rs/G2017/Pdf/G20176006.pdf

8. Republički Zavod za Statistiku (2018). Upotreba Informacionokomunikacionih Tehnologija u Republici Srbiji; Domaćinstva/Pojedinci, Preduzeća, Republički Zavod za Statistiku, Beograd, access July 2019 http://publikacije.stat.gov.rs/G2018/Pdf/G201816013.pdf

9. Rosenbloom, B. (2007). Multi-channel strategy in business-to-business markets: prospects and problems. Industrial marketing management, 36(1), 4-9.

10. Statista, (2019). Most Famus Social Networks Sites Worldwide as of April 2019, Ranked by Number of active Users (In Millions), access June 2019 https://www.statista.com/statistics/272014/global-social-networksranked-by-number-of-users /

11. Wang X, Abdullayeva G., (2011). The Realtionship Between Use of Social Media and Customer Relationship; From E/commerce Model Perspective, Master Thesis 15 HEC, INFM02 in informatics, School of Economics and Management, Lund University, Department of Informatics

12. Yannopoulos, P. (2011). Impact of the Internet on Marketing Strategy Formulation, International Journal of Business and Social Science, 2(18), 1-7.

\title{
KUPOVNO PONAŠANJE KORISNIKA INTERNETA U SRBIJI
}

\author{
Đurić Slađana
}

Sažetak: Internet sa svojim medijima i platformama je postao neizbežan deo $i$ moćno sredstvo današnjeg poslovanja. Marketari 
koriste Internet $i$ njegov potencijal za lansiranje onlajn reklamnih kampanja $i$ za uspostavljanje $i$ održavanje uspešnih dugoročnih odnosa sa svojim kupcima. Odnosi sa kupcima zasnovani na upotrebi digitalnih tehnologija i Interneta preneli su komunikaciju između kompanija i njihovih kupaca u onlajn prostor i postali najvažniji alat za postizanje konkurentske prednosti na današnjem turbulentnom tržištu. Rezultati istraživanja prikazani u ovom radu su značajan deo šireg istraživanja koje je autor sproveo kako bi istražio realne stavove građana Srbije vezane za upotrebu Interneta, društvenih medija i kupovnog ponašanja na Internetu.

Ključne reči: Internet / društveni mediji / društvene mreže / višestruki kanali distribucije / internet kupovina / istraživanje 